\title{
Morphological and immunohistochemical investigations of endometrial biopsies in mule mares
}

\author{
Heidrun Huth', Christin Ellenberger ${ }^{1}$, Claus-Peter Bartmann², Julia Rass², Hans-Otto Hoppen ${ }^{3}$ and Heinz-Adolf Schoon ${ }^{7}$ \\ Institut für Veterinär-Pathologie, Universität Leipzig ${ }^{1}$, Einsatz- und Ausbildungszentrum für Gebirgstragtierwesen, Bad Reichenhall² and Zentrumsabteilung für \\ Chemische Analytik und Endokrinologie, Stiftung Tierärztliche Hochschule Hannover ${ }^{3}$
}

\begin{abstract}
Summary
The aim of the present study was an (immuno-) histological characterisation of endometrial functional morphology in mule mares with respect to clinical and endocrinological parameters. The results were also compared to observations in the horse. From six mule mares (13-23 years old) endometrial biopsies ( $n=97$ ) were recurrently collected over a period of approximately 4 months (April - August). Clinically, two mules showed an erratic estrus cycle with considerably varying serum estradiol and progesterone values. Histologically, these two animals revealed a variable functional morphology with marked endometrial maldifferentiation. The proliferation activity and expression of steroid hormone receptors was also variable. These results resemble findings in the transitory period between ovulatory season and winter anestrous in horses. No correlation between the clinical or endocrinological data and the endometrial functional morphology could be observed in either mule. Four mule mares showed acyclia during the whole period of clinical observation. Serum hormone concentrations remained on a rather constant level. Histologically, the four mules presented an inactive but irregular differentiated endometrium with variable estrogen and progesterone receptor expression and little proliferation activity. The described findings are comparable with observations in winter anestrus or inactivity during the breeding season in horses.
\end{abstract}

Keywords: mule, endometrium, estrus cycle, endometrial functional morphology, immunohistochemistry

\section{Morphologische und immunhistologische Untersuchungen an Endometriumbioptaten von Maultierstuten}

Ziel der vorliegenden Studie war eine (immun-) histologische Charakterisierung der endometrialen Funktionsmorphologie bei Maultieren in Abhängigkeit von klinischen und endokrinologischen Parametern. Die Ergebnisse sollten mit den Erkenntnissen bei der Pferdestute verglichen werden. Es standen dazu 6 Maultierstuten im Alter von 13 bis 23 Jahren zur Verfügung, bei denen über einen Zeitraum von 4 Monaten (April bis August) regelmäßig Endometriumbioptate $(n=97)$ entnommen wurden. Zwei der Tiere zeigten laut klinischem Vorbericht ein unregelmäßiges Zyklusgeschehen mit stark schwankenden Serumöstradiol- und -progesteronwerten. Histologisch konnte bei beiden Maultieren eine variable endometriale Funktionsmorphologie mit teils ausgeprägter Fehldifferenzierung sowie eine ebenfalls variable Proliferationsaktivität und Steroidhormonrezeptorexpression festgestellt werden. Die erhobenen histomorphologischen und immunhistologischen Befunde sind vergleichbar mit denen bei Pferdestuten in den Übergangszyklen. Es zeigte sich bei beiden untersuchten Maultieren keine Korrelation zwischen den vorberichtlich angegebenen klinisch-endokrinologischen Parametern und der endometrialen Funktionsmorphologie. Bei 4 Maultierstuten wurde klinisch eine Azyklie mit wenig schwankenden Serumhormonwerten festgestellt. Histologisch konnte bei allen 4 Stuten ein inaktives, jedoch irregulär differenziertes Endometrium vorgefunden werden. Es zeigte sich zudem eine deutlich variable Expression der Östrogen- und Progesteronrezeptoren bei vereinzelter Proliferationsaktivität. Die erhobenen Befunde sind mit denen von Pferdestuten im Winteranöstrus bzw. im Anöstrus während der physiologischen Decksaison vergleichbar.

Schlüsselwörter: Maultier, Endometrium, Zyklus, endometriale Funktionsmorphologie, Immunhistologie

\section{Introduction}

Mules belong to the (mostly infertile) equine hybrids. The differences between the parental sets of chromosomes in number (female horse: $2 n=64$, male donkey: $2 n=62$ ) and structure lead to a meiotic arrest, resulting in a decreased number of oocytes at birth (Möllmann 1991, Allen and Short 1997). As described in literature mules clinically show either an estrus cycle or acyclia (Möllmann 1991, Bartmann et al. 2008) and have been successfully used as recipients in embryo transfer techniques (Allen and Short 1997). However, systematic morphological and functional investigations of the endometrium of these equine hybrids do so far not exist.

Compared to that in horses the endometrial functional morphology at the different stages of the estrus cycle is well known (Kenney 1978, Kenney and Doig 1986, Brunckhorst et al. 1991, Ginther 1992, Strankmeyer 1993, Häfner 1999) and their estrus cycle can be diffentiated in proestrus, estrus, postestrus and interestrus (Schoon et al. 1992). The average length of the equine estrus cycle is 22 days, individual variations are frequent (Ginther 1992). In mares a characteristic expression of estrogen and progesterone receptors according to the different stages of cycle has been described (Gerstenberg et al. 1999, Häfner 1999, Aupperle et al. 2000, Özgen et al. 2002). Physiologically, an intense steroid hormone receptor expression within the epithelia corresponds with a weak stromal reaction and vice versa.

During winter anestrus mares show an inactive endometrium associated with mild proliferation activity and a varying steroid hormone receptor expression (Kenney 1978, Ginther 1992, Aupperle et al. 2003, Gockeln et al. 2006). Temporary endometrial maldifferentiation can be observed in some mares during the transitory period between ovulatory season 
and winter anestrous (Schoon 2007, unpublished data). Two main features of endometrial maldifferentiation have been described in horses: irregular and unequal differentiation (Häfner 1999, Ellenberger 2003). While irregular endometrial maldifferentiation is interpreted as a sign of general hormonal imbalances, the unequal differentiation is known to be an expression of a partially hormone refractory endometrium (Häfner 1999, Schoon et al. 2000).

The aim of the present study was the (immuno-) histological investigation of endometrial biopsies taken from clinically cyclic and acyclic mule mares documenting the endometrial functional morphology, steroid hormone receptor expression and proliferation activity. Possible correlations between clinical and/or endocrinological data and the histomorphological findings were considered and the results were compared to findings in the horse.

\section{Materials and methods}

Biopsy samples $(n=97)$ were taken from six mule mares (1323 years old) over a period of 4 months (in one case over 7 months) during spring and summer in 2004. Simultaneously, gynaecological examinations were performed and serum estradiol and progesterone levels were determined (Bartmann et al. 2008).

\section{Clinical data}

Two animals showed an erratic estrus cycle with ovulations and a striking variability in the length of the cycles. During the whole period of clinical observation the mule 1 had two cycles with a length of 112 and 60 days, respectively (Bartmann et al. 2008).

In both mules variable serum estradiol and progesterone levels were measured (Tab. 1), which did not correspond to the gynaecologically documented stages of cycle (proestrus, estrus, postestrus, interestrus and anestrus) (Bartmann et al. 2008). Clinically, four mule mares showed acyclia associated with constant low serum hormone levels (Bartmann et al. 2008, Tab. 2).

\section{Histology}

Directly after sample taking, the endometrial biopsies were fixed in $4 \%$ buffered formalin, embedded in paraplast, sectioned and stained routinely with Hämalaun-Eosin (H.E.).

The lightmicroscopical investigation was performed according to the criteria described by Häfner (1999), Schoon et al. (2000) and Ellenberger (2003).

\section{Immunohistochemistry}

Immunohistochemistry was performed with the peroxidase anti-peroxidase-technique using the proliferation marker Ki-67 antigen ${ }^{1}$ as well as estrogen ${ }^{1}$ and progesterone ${ }^{2}$ receptor markers. The semi-quantitative evaluation of steroid hormone receptor expression (resulting in a immunoreactive score) followed a method established by Özgen et al. 2002.

The expression of $\mathrm{Ki}-67$ antigen was quantified by estimating the number of positive reacting cells using the following grading: = no positive reacting cells, $((+))=$ very few positive reacting cells, $(+)=$ few positive reacting cells, $+=$ small number of positive reacting cells, $++=$ moderate number of positive reacting cells and $+++=$ high number of positive reacting cells.

\section{Results \\ Cyclic mule mares \\ Histomorphology}

Both mule mares showed a varying endometrial functional morphology without any correlation to the clinically documented stage of cycle and the serum hormone concentrations. Endometrial maldifferentiation (irregular and unequal glandular differentiation) was obvious in most biopsies (Fig. 1 and 2) with a proliferative (Fig. 1), secretory (Fig. 2) or inactive basic functional morphology. The most pronounced sign of irregular endometrial differentiation was the marked poly-

Table 1 Serum hormone concentrations and total number of collected endometrial biopsies in two clinically "cyclic" mule mares. Serumhormonkonzentrationen und Anzahl der entnommenen Endometriumbioptate bei zwei klinisch "zyklischen" Maultierstuten.

\begin{tabular}{lccc}
\hline Mules & Estradiol $[\mathrm{pg} / \mathrm{ml}]$ & Progesterone $[\mathrm{ng} / \mathrm{ml}]$ & Number of collected biopsy samples \\
\hline Mule 1 & $<1.0-15.0$ & $0.23-9.8$ & 40 \\
Mule 2 & $4.9-14.0$ & $0.86-9.1$ & $11^{*}$ \\
\hline
\end{tabular}

Legend: " thereof 7 biopsies not analysable due to sampling close to the cervix uteri

Table 2 Serum hormone concentrations and total number of collected endometrial biopsies in four clinically acyclic mule mares. Serumhormonkonzentrationen und Anzahl der entnommenen Endometriumbioptate bei vier klinisch azyklischen Maultierstuten.

\begin{tabular}{cccc}
\hline Mules & Estradiol $[\mathrm{pg} / \mathrm{ml}]$ & Progesterone $[\mathrm{ng} / \mathrm{ml}]$ & Number of collected biopsy samples \\
\hline Mule 3 & $7.0-10.8$ & $0.28-1.0$ & $11^{*}$ \\
Mule 4 & $10.8-14.5$ & $0.63-1.1$ & 11 \\
Mule 5 & $7.8-13.7$ & $0.59-0.85$ & 11 \\
Mule 6 & $9.3-14.2$ & $0.25-0.97$ & 13 \\
\hline
\end{tabular}

Legend: "thereof 1 biopsy not analysable due to sampling close to the cervix uteri 
morphism of the glandular epithelia within the cross-sections of single glands. Unequal endometrial differentiation was characterised by the coexistence of different types of glandular functional morphology or activity in non-fibrotic areas in one biopsy.

Additionally, a moderate, partially mixed, partially inactive and focally destructive endometrosis could be diagnosed (Fig. 3).

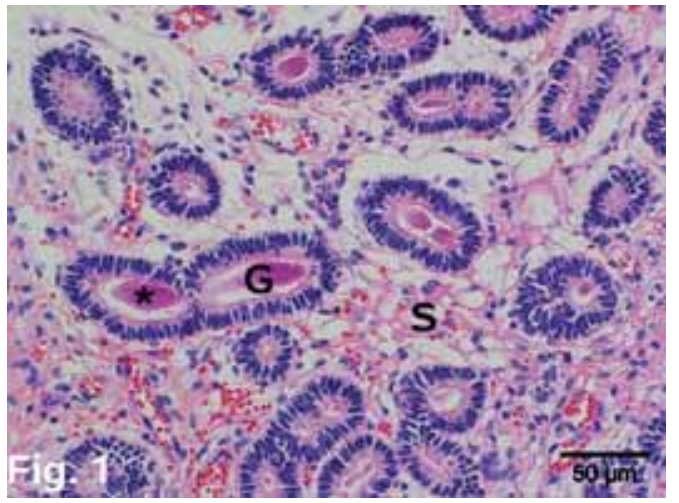

Fig 1 Mule 1, day 16 of estrus cycle: irregular proliferative endometrial differentiation; inspissated secretory remnants (asterisk) within the glands (G); stromal cells (S), H.E.-stain.

Maultierstute 1, Zyklustag 16: irregulär proliferative endometriale Differenzierung; eingedicktes Restsekret (asterisk) in den Drüsen (G), Stromazellen (S), H.E.-Färbung.

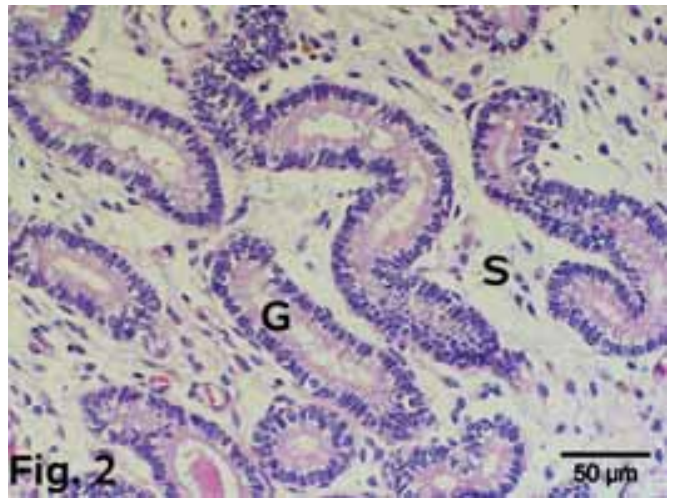

Fig 2 Mule 1, day 79 of estrus cycle: irregular secretory endometrial differentiation; glands (G), stromal cells (S), H.E.-stain.

Maultierstute 1, Zyklustag 79: irregulär sekretorische endometriale Differenzierung; Drüsen (G), Stromazellen (S), H.E.-Färbung.
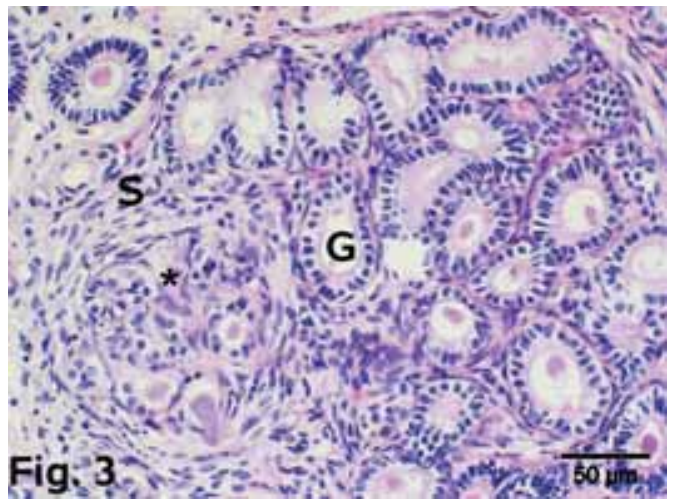

Fig 3 Mule 1, day 23 of estrus cycle: mixed, focally destructive (asterisk) endometrosis; glands (G), stromal cells (S), H.E.-stain. Maultierstute 1, Zyklustag 23: gemischte, fokal destruierende (asterisk) Endometrose; Drüsen (G), Stromazellen (S), H.E.-Färbung.
Immunohistochemistry

The expression pattern of estrogen and progesterone receptors was highly variable (Table 3 ) and did not relate to the endometrial functional morphology. A coexistence of synchronous (Fig. 4) or asynchronous (Fig. 5) expression patterns between glandular epithelia and stromal cells could be observed with a patchy staining intensity of the endometrial structures, particularly visible in the cross-sections of the

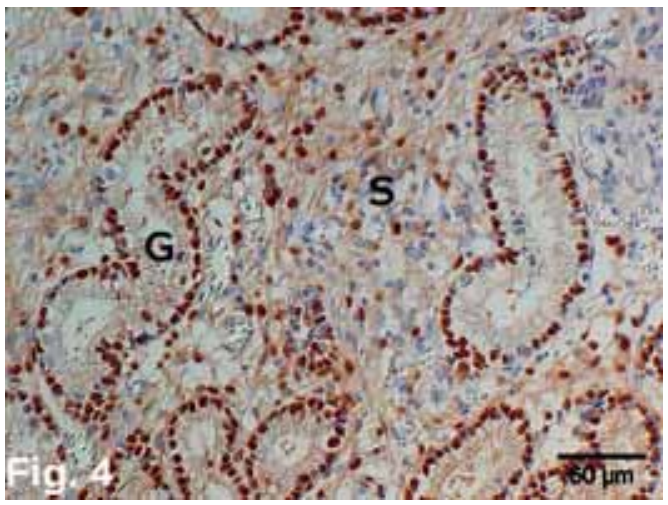

Fig 4 Mule 1, day 79 of estrus cycle (irregular secretory endometrial differentiation): expression of estrogen receptors: moderate and patchy within the glands $(G)$, moderate within the stromal cells $(S)$, immunohistochemistry, Nomarski-interference-contrast.

Maultierstute 1, Zyklustag 79 (irregulär sekretorische endometriale Differenzierung): Östrogenrezeptorexpression: mittelgradig und ungleichmäßig in den Drüsen (G), mittelgradig in den Stromazellen (S), Immunhistologie, Nomarski-Interferenzkontrast.

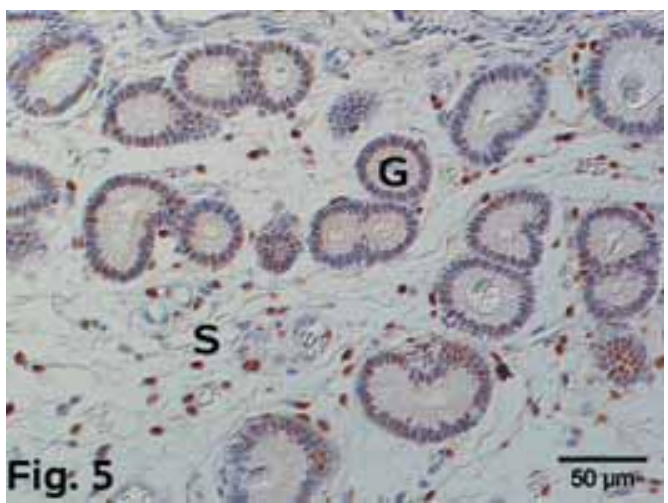

Fig 5 Mule 1, day 16 of estrus cycle (irregular proliferative endometrial differentiation): expression of progesterone receptors: sporadic and patchy within the glands $(G)$, mild to moderate within the stromal cells (S), immunohistochemistry, Nomarski-interference-contrast.

Maultierstute 1, Zyklustag 16 (irregulär proliferative endometriale Differenzierung): Progesteronrezeptorexpression: vereinzelt und ungleichmäßig in den Drüsen (G), gering- bis mittelgradig in den Stromazellen (S), Immunhistologie, Nomarski-Interferenzkontrast.

endometrial glands (Fig. 4 and 5). The proliferation activity ranged from negative to moderate without any link to the expression pattern of steroid hormone receptors.

Non cyclic mule mares Histomorphology

Corresponding to the clinically documented acyclia histomorphological investigations revealed inactive and partially irre- 
Table 3 Clinical, endocrinological and (immuno-) histological results at selected days of the estrus cycle regarding the mule 1. Darstellung klinischer, endokrinologischer und (immun-) histologischer Ergebnisse an ausgewählten Zyklustagen der Stute 1.

\begin{tabular}{|c|c|c|c|c|}
\hline Mule 1 & $43^{\text {rd }}$ day of cycle (I) & $94^{\text {th }}$ day of cycle (I) & $112^{\text {nd }}$ day of cycle (I) & $16^{\text {th }}$ day of cycle (II) \\
\hline Clinical stage of cycle & Interestrus & Interestrus & Estrus & Interestrus \\
\hline Estradiol $[\mathrm{pg} / \mathrm{ml}]$ & 1.9 & 4.7 & 11.0 & $*$ \\
\hline Progesterone $[\mathrm{ng} / \mathrm{ml}]$ & 0.60 & 0.65 & 0.59 & 0.65 \\
\hline Endometrial functional morphology & irregular-inactive & irregular-secretory & irregular- secretory & irregular- proliferative \\
\hline IRS ER glands & 1.9 & 4.9 & 7.9 & 0.4 \\
\hline IRS ER stromal cells & 4.6 & 5.2 & 5.2 & 1.3 \\
\hline IRS PR glands & 4.1 & 0.8 & 7.5 & 0.6 \\
\hline IRS PR stromal cells & 5.3 & 3.2 & 8.0 & 2,3 \\
\hline Ki-67 glands & $(+)$ & $+(+)$ & $+(+)$ & $(+)$ \\
\hline Ki-67 stromal cells & $((+))$ & $\varnothing$ & + & $\varnothing$ \\
\hline
\end{tabular}

$\mathrm{I}=1^{\text {st }}$ estrus cycle (1 12 days) $\quad$ ER $=$ estrogen receptor expression $\|=2^{\text {nd }}$ estrus cycle (60 days) PR $=$ progesterone receptor expression

IRS = immuno reactive score $\quad *=$ missing $\varnothing=$ no positive reacting cells, $((+))=$ very few positive reacting cells

$(+)=$ few positive reacting cells, $+=$ small number of positive reacting cells, $+(+)=$ small to moderate number of positive reacting cells

gular differentiated endometria in all four mules (Fig. 6). The irregular glandular differentiation was particularly characterized by a marked polymorphism of the glandular epithelia. Predominantly one-layered cuboidal luminal and glandular

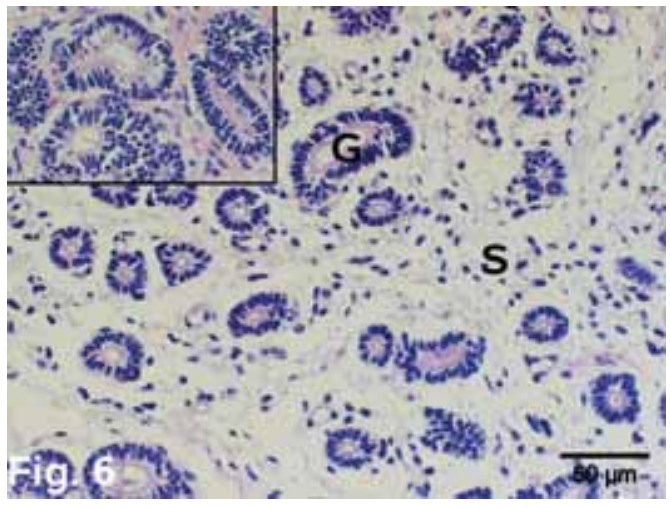

Fig 6 Acyclic mule 6, 14th June 2004: irregular inactive endometrial differentiation; glands $(G)$, stromal cells $(S)$, inset: hyperplastic glandular epithelia, H.E.-stain.

Azyklische Maultierstute 6, 14.06.2004: irregulär inaktive endometriale Differenzierung; Drüsen (G), Stromazellen (S), Inset: hyperplastische Drüsenepithelien, H.E.-Färbung.

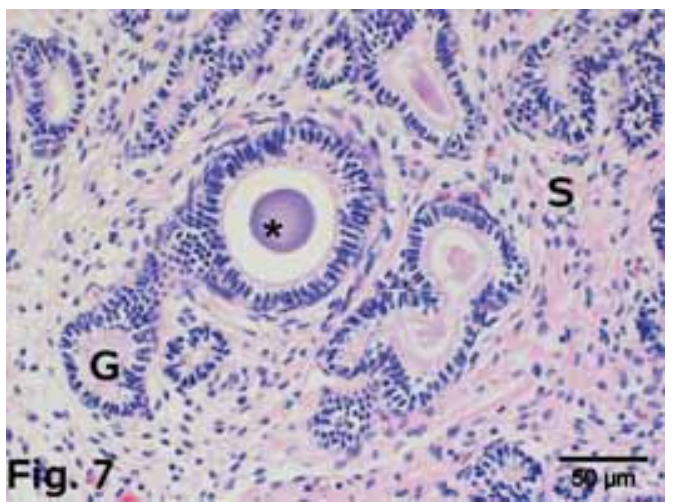

Fig 7 Acyclic mule 6, 12th May 2004: mixed endometrosis with inspissated secretory remnants (asterisk) within the glands $(G)$; stroma (S), H.E.-stain.

Azyklische Maultierstute 6, 12.05.2004: gemischte Endometrose mit verkalktem Restsekret (asterisk) in den Drüsen (G); Stromazellen (S), H.E.-Färbung. epithelia with a compact cytoplasm and small, round to oval, partially bolt-like, longish, hyperchromatic nuclei and narrow glandular lumina could be observed. In some areas hyperplastic glandular epithelia were visible (Fig. 6, Inset). Glandular density was low to moderate and they appeared to be mostly non tortuous. Mild stromal edema and a mild to moderate stromal activity were present. In addition to that, all animals showed a gradually varying, predominantly mixed and focally destructive endometrosis (Fig. 7).

\section{Immunohistochemistry}

A variable expression of steroid hormone receptors in the endometrial glands as well as in the stromal cells (Tab. 4) was found in all mules of the non cyclic group. In the majority of the investigated biopsies a patchy hormone expression pattern in the cross-sections of the endometrial glands was obvious (Fig. 8). Ki-67 antigen expression was negative or only a few positive reacting cells (epithelial and stromal cells) could be found.

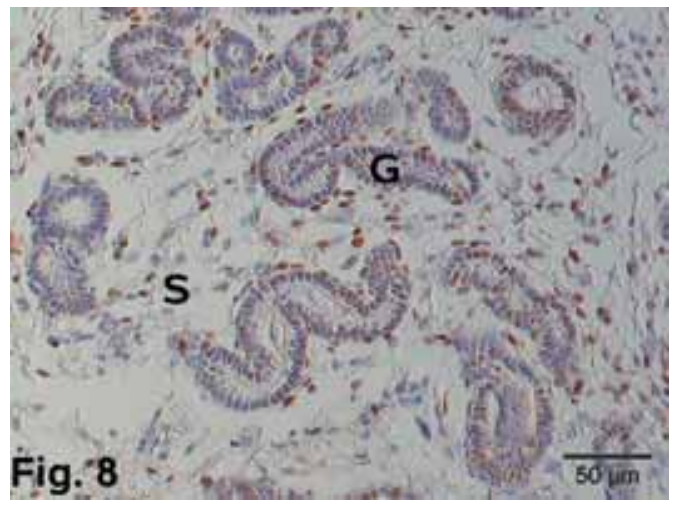

Fig 8 Acyclic mule 6, 23rd June 2004 (irregular inactive endometrial differentiation): expression of progesterone receptors: sporadic and patchy within the glands $(G)$, mild to moderate within the stromal cells $(S)$, immunhistochemistry, Nomarski-interferencecontrast.

Azyklische Maultierstute 6, 23.06.2004 (irregulär inaktive endometriale Differenzierung): Progesteronrezeptorexpression: vereinzelt und ungleichmäßig in den Drüsen (G), gering-bis mittelgradig in den Stromazellen (S), Immunhistologie, Nomarski-Interferenzkontrast. 
Table 4 Clinical, endocrinological and (immuno-) histological results at selected days of biopsy collection regarding the acyclic mule Claudia. Darstellung klinischer, endokrinologischer und (immun-) histologischer Ergebnisse an ausgewählten Bioptat-Entnahmetagen bei der Stute Claudia

\begin{tabular}{|c|c|c|c|c|}
\hline Mule 6 & $17^{\text {th }}$ April 2004 & $12^{\text {th }}$ May 2004 & $14^{\text {th }}$ June 2004 & $1^{\text {st }}$ July 2004 \\
\hline Clinical stage of cycle & Acyclia & Acyclia & Acyclia & Acyclia \\
\hline Estradiol $[\mathrm{pg} / \mathrm{ml}]$ & 12.9 & 12.1 & 9.3 & 10.6 \\
\hline Progesterone [ng/ml] & 0.97 & 0.88 & 0.63 & 0.25 \\
\hline Endometrial functional morphology & irregular-inactive & irregular-inactive & irregular-inactive & irregular-inactive \\
\hline IRS ER glands & 1.9 & 0.3 & 4.5 & 5.2 \\
\hline IRS ER stromal cells & 5.2 & 1.6 & 5.2 & 6.0 \\
\hline IRS PR glands & 0.3 & 0.1 & 0.2 & 3.7 \\
\hline IRS PR stromal cells & 5.7 & 3.2 & 2.8 & 2.3 \\
\hline Ki-67 glands & $((+))$ & $\varnothing$ & $((+))$ & $\varnothing$ \\
\hline Ki-67 stromal cells & $(+)$ & $\varnothing$ & $(+)$ & $\varnothing$ \\
\hline
\end{tabular}

$E R=$ estrogen receptor expression $\quad P R=$ progesterone receptor expression $\quad I R S=$ immuno reactive score

$\varnothing=$ no positive reacting cells, $((+))=$ very few positive reacting cells, $(+)=$ few positive reacting cells

\section{Discussion}

The results of the present study show, that beside a variable endometrial functional morphology, the investigated cyclic mule mares reveal a distinct endometrial maldifferentiation. In mules two major features of endometrial maldifferentiation can be distinguished: the unequal and the irregular differentiation, combined with an inactive, secretory or proliferative basic functional morphology as described by Häfner (1999) and Schoon et al. (1999) in horses. The discrepancy between the clinically and endocrinologically documented stage of cycle and the (immuno-) histological endometrial functional morphology in the biopsy samples was striking. For instance on 24th of May 2004 mule 1 was in interestrus according to the gynaecologically documented stage of cycle as a corpus luteum was identified on the left ovary. Serum estradiol and progesterone levels measured $4.0 \mathrm{pg} / \mathrm{ml}$ and $3.0 \mathrm{ng} / \mathrm{ml}$ (Bartmann et al. 2008). Non the less, ligtmicroscopical investigation revealed an irregular and inactive endometrium.

Hence, in both cyclic mule mares no conclusions could be drawn from the histological endometrial findings to the clinical and endocrinological data. In horses endometrial maldifferentiation is generally caused by hormonal disturbances, including ovarian disorders (Häfner 1999, Schoon et al. 1999, Ellenberger 2003). Furthermore maldifferentiated endometria in the mare can regularly be seen in routine diagnostic during the transitory period between ovulatory season and winter anestrus (Schoon 2007, unpublished data). In the group of cyclic mules the expression of steroid hormone receptors was also highly variable. No obvious correlation to clinical, endocrinological and histomorphological findings could be observed. The patchy immunolabelling of the steroid hormone receptor within cross-sections of the endometrial glands can be interpreted as an expression of endometrial maldifferentiation.

In horses a maximal glandular proliferation activity can be seen from day 3 to 7 of early interestrus (Gerstenberg et al. 1999). The group of cyclic mules showed a completely lakking to moderate glandular proliferation activity. A characteristic stage of cycle dependent $\mathrm{Ki}-67$ antigen expression pattern as described in horses (Gerstenberg et al. 1999, Aupperle et al. 2000) could not be found.
A conclusive statement regarding the etiopathogenesis of endometrial maldifferentiation in mules cannot be made at this point. The condition may be caused by disturbances of endocrine regulation mechanisms or disturbances on the endometrial hormone receptor level.

The clinically acyclic group of mules showed inactive (functional morphology and $\mathrm{Ki}-67$ antigen expression) but irregular differentiated endometria. The varying steroid hormone receptor expression intensity and the patchy expression pattern within the glandular epithelia stands as a feature of endometrial maldifferentiation. Those results are comparable to findings in horses during the winter anestrus or anestrus during the breeding season (Aupperle et al. 2003).

In addition, all mules (13 to 23 years old) exhibited endometrosis varying in quality and quantity, which is most likely a matter of a non reversible, degenerative, age-associated disease as described in horses (Kenney 1978, Schoon et al. 1997). In spite of the high frequency of biopsy sampling in each animal, no clinical or histological signs of endometrial inflammaton (with the exception of one biopsy of one mule) could be registered during the whole period of investigation. Hence, it can be stated that the endometrial biopsy is a save and appropriate method for longterm investigations in mule mares (Bartmann et al. 2008).

Summing up, infertility in mules is mainly based on genetical aspects (Benirschke et al.1964, Möllmann 1991, Allen and Short 1997), but it seems possible that additional phenomena like endometrial maldifferentiation associated with disturbances in the endometrial steroid hormone receptor status have an influence, too. Due to the small number of individuals investigated in this study, the results should not be uncritically applied to the whole population of mules.

\section{Manufacturer's address}

1 Novocastra, Newmarket, UK

\section{References}

Allen W. R. and Short R. V. (1997) Interspecific and extraspecific pregnancies in equids: anything goes. J. Hered. 88, 384-392 
Aupperle H., Özgen S., Schoon H.-A., Schoon D., Hoppen H. O., Sieme H. and Tannapfel A. (2000) Cyclical endometrial steroid hormone receptor expression and proliferation intensity in the mare. Equine Vet. J. 32, 228-232

Aupperle H., Steiger K., Reischaver A. and Schoon H.-A. (2003) Ultrastructural and immunohistochemical characterization of the physiological and pathological inactivity of the equine endometrium. Pferdeheilkunde 19, 629-632

Bartmann C. P., Rass J., Hoppen H. O., Ellenberger C., Huth H. and Schoon H.-A. (2008) Clinical, histological and endocrinological findings concerning the sexual cycle in female mules. Pferdeheilkunde 24, in press

Benirschke K., Low R. J., Sullivan M. M. and Carter R. M. (1964) Chromosome study of an alleged fertile mare mule. J. Hered. 55, $31-38$

Brunckhorst D., Schoon H.-A., Bader H. and Sieme H. (1991) Morphological, enzymatic and immunohistochemical characteristics of the endometrial cycle in the mare. Fertilität 7, 44-51

Ellenberger C. (2003): Funktionelle Pathologie des equinen Ovars und daraus resultierende endometriale Differenzierungsstörungen - Histomorphologische und immunhistologische Untersuchungen. Universität Leipzig, Veterinärmedizinische Fakultät, Thesis

Gerstenberg C., Allen W. R. and Stewart F. (1999) Cell proliferation patterns in the equine endometrium throughout the non-pregnant reproductive cycle. J. Reprod. Fertil. 1 16, 167-175

Ginther O. J. (1992) Characteristics of the ovulatory season. In: Reproductive biology of the mare. Basic and applied aspects. ed. O. J. Ginther, 2nd ed, Equiservices, Wisconsin, 173-232

Gockeln R., Aupperle H., Sieme H., Klug E., Einspanier A. and Schoon H. -A. (2006) Studies on the correlationship between ovarian activity, serological findings and the endometrial morphology during the non-breeding season in mares. 39th Annual conference of physiology and pathology of reproduction, Hannover 2006, Reprod. Dom. Anim. Vol. 41 Suppl. 1, p. 13

Häfner I. (1999) Differenzierungsstörungen im Endometrium der Stute - Lichtmikroskopische und immunhistologische Untersuchungen. Universität Leipzig, Veterinärmedizinische Fakultät, Thesis

Kenney R. M. (1978) Cyclic and pathologic changes of the mare endometrium as detected by biopsy, with a note on early embryonic death. J. Am. Vet. Med. Assoc. 172, 241-262

Kenney R. M. and Doig P. A. (1986) Equine endometrial biopsy. In: Current Therapy in Theriogenology, ed. D. A. Morrow, 2nd ed., WB Saunders Comp., Philadelphia, 723-729

Möllmann T. (1991) Zum Reproduktionsgeschehen beim weiblichen Maultier. Ludwig-Maximilians-Universität München, Tierärztliche Fakultät, Thesis

Özgen S., Schoon H.-A., Aupperle H., Sieme H. and Klug E. (2002) Etiopathogenesis of equine intrauterine fluid accumulation. Pferdeheilkunde 18, 594-599

Schoon H.-A., Schoon D. and Klug E. (1992) Uterusbiopsien als Hilfsmittel für Diagnose und Prognose von Fertilitätsstörungen der Stute. Pferdeheilkunde 8, 355-362

Schoon H.-A., Schoon D. and Klug E. (1997) Die Endometriumbiopsie bei der Stute im klinisch-gynäkologischen Kontext. Pferdeheilkunde 13, 453-464

Schoon H.-A., Schoon D., Wiegandt I., Bartmann C.-P. and Aupperle H. (1999)"Endometrial maldifferentiation" - A clinically significant diagnosis in equine reproduction? Pferdeheilkunde 15, 555-559

Schoon H.-A., Wiegandt I., Schoon D., Aupperle H. and Bartmann C.-P. (2000) Functional disturbances in the endometrium of barren mares: a histological and immunohistological study. J. Reprod. Fertil. Suppl. 56, 381-391

Strankmeyer O. (1993) Morphometrische Untersuchungen am Endometrium zyklischer und ovariektomierter, hormonbehandelter Stuten. Hannover, Tierärztliche Hochschule, Thesis

Heidrun Huth

Institut für Veterinär-Pathologie

An den Tierkliniken 33

04103 Leipzig

huth@rz.uni-leipzig.de 